\title{
Pembuatan Sistem Pencarian Pekerjaan Menggunakan TF-IDF
}

\author{
Arif Tirtana $^{1}$, Adnan Zulkarnain ${ }^{2}$, Yohanes Dwi Listio ${ }^{3}$ \\ STIKI Malang \\ 1arif.tirtana@ stiki.ac.id, ${ }^{2}$ adnan.zulkarnain@ @stiki.ac.id, ${ }^{3}$ yohanes@ @stiki.ac.id
}

\begin{abstract}
ABSTRAK.Seiring berjalannya waktu, kehidupan manusia terus mengalami perubahan.Begitu pula untuk konteks pekerjaan manusia sebagai kegiatan untuk pemenuhan kebutuhan. Namun dalam proses penyampaian informasi pekerjaan masih terkendala proses penyampaian informasi dari penyedia pekerjaan kepada pencari pekerjaan, sehingga berdampak kepada para pencari pekerjaan yang kesulitan untuk mendapat informasi tentang lowongan pekerjaan, maupun proses pendaftaran pada pekerjaan sesuai dengan keinginan pencari kerja. Dari permasalahan diatas maka diperlukan sebuah keterbaruan dalam mempermudah para pencari pekerjaan dalam pencarian pekerjaan ini, dalam hal ini pencarian lowongan pekerjaan.Pada penelitian ini dibuat sebuah mesin pencari untuk memudahkan para pencari kerja dalam mendapatkan informasi pekerjaan sesuai dengan kata kunci yang dimasukkan oleh pengguna, menggunakan metode TF-IDF. Hasil pengujian sistem menunjukkan metode TF-IDF lebih lama dalam proses pencarian dibandingkan dengan full query tetapi memberikan hasil pencarian yang lebih relevan dibandingkan dengan full query.
\end{abstract}

Kata Kunci: mesin pencari, pekerjaan, information retrieval, TF-IDF.

\begin{abstract}
Over time, human life continues to change. Likewise for the context of human work as an activity to fulfill needs. However, in the process of delivering information work is still constrained by the process of delivering information from job providers to job seekers, thus impacting job seekers who have difficulty getting information about job vacancies, as well as the process of registering for jobs in accordance with the wishes of job seekers. From the problems above, we need an update to make it easier for job seekers to find jobs, in this case the search for job vacancies. In this study a search engine was created to make it easier for job seekers to get job information in accordance with the keywords entered by users, using the TF-IDF method. The results of the system testing show that the TF-IDF method is longer in the search process compared to the full query but provides more relevant search results than the full query.
\end{abstract}

Keywords: search engine, job, information retrieval, TF-IDF.

\section{PENDAHULUAN}

Menurut data dari Badan Pusat Statistik (BPS), tingkat pengangguran terbuka di Indonesia (TPT) pada bulan Februari 2019 sebesar 5,01\% dari jumlah penduduk Indonesia usia kerja yaitu sebesar 6,82 juta orang, jumlah tersebut sudah mengalami peningkatan jika dibandingkan dengan jumlah TPT pada Februari 2018 yakni sebesar 5,13\% dari jumlah penduduk usia kerja yaitu sebesar 6,87 juta orang, dari data tersebut jumlah TPT berkurang sebanyak 50 ribu orang(Statistik, 2019).Namun jumlah TPT sebanyak 6,82 juta orang tersebut bukan jumlah yang sedikit, dan harus diperbaiki dari waktu ke waktu. Ada beberapa faktor yang menjadi kendala ketika mencari pekerjaan dan pada akhirnya mempengaruhi seseorang dalam mencari pekerjaan, salah satunya adalah sulitnya untuk mendapat informasi lengkap mengenai lowongan pekerjaan (Anissatush Sholiha, Rochdi Wasono, 2010).

Mesin pencari merupakan sebuah alat bantu yang digunakanuntuk membantu pengguna dalam mencari informasi sesuai dengan kata kunci (keyword) yang dimasukkan. Mesin pencari yang handal memiliki kemampuan untuk menampilkan informasi yang tepat dan juga akurat (Putu Wuri Handayani, I Made Wiryana, 2017).Mesin pencari atau sering disebut dengan sistem temu kembali (information retrieval system)yang ada saat ini telah banyak dibuat, namun tidak semua mesin pencari memberikan hasil pencarian yang relevansehingga menyebabkan sulitnya masyarakat untuk mendapat informasi yang cepat dan akurat(Amin \& Purwatiningtyas, 2015).Oleh karena itu diperlukan adanya metode untuk memperbaiki kekurangan tersebut. Salah satu metode yang memiliki kemampuan tersebut adalah metode TF-IDF (Fitri, 2017).Dari penjelasan yang telah disampaikan sebelumnya, maka dalam penelitian ini akan membuat sistem pencarian pekerjaan menggunakan TF-IDF yang diberi nama JobFinder.

\section{METODOLOGI PENELITIAN}

Dari studi literatur dan penelitian terkait sebelumnya, maka pada penelitian ini disusun metodologi penelitian yang dibagi menjadi beberapa tahap, antara lain pada tahap pertama dilakukan studi literaturyang mencakup kajian penelitian terdahulu terkait dengan pembuatan mesin pencari, information retrieval, dan 
mempelajari perhitungan dan algoritma metode Term Frequency Inverse Document Frequency (TF-IDF). Pada tahap kedua dilakukan tahap pengumpulan data (crawling data)dengan menggunakan tools yang disematkan dalam browser yaitu menggunakan Web Scrapper, proses pengumpulan data (crawling)pencarian pekerjaandiambil dari 5 website pencarian pekerjaan, antara lain jobstreeet.com, jobsdb.com, karir.com, careerbuilder.com dan jobsid.com.Adapun tahapan pengumpulan data terdapat pada gambar 1 di bawah ini.

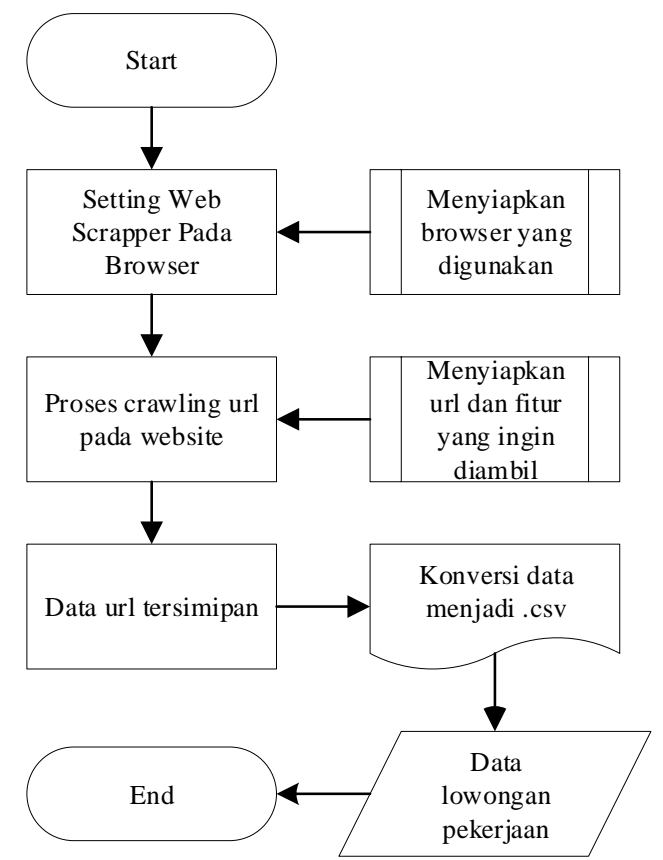

Gambar 1 Alur Pengumpulan Data

Tahap ketiga yaitu tahap seleksi data, apakah data yang telah dikumpulkan sebelumnya sudah sesuai atau masih perlu perbaikan, jika data yang dikumpulkan telah sesuai maka dilanjutkan pada tahap pembuatan program, dan jika data yang dikumpulkan belum sesuai maka dilakukan tahap crawling data ulang. Setelah tahap pengumpulan data dilakukan, perlu dilakukan perhitungan manual untuk menyusun algoritma pemrograman dengan menggunakan bahasa PHP dengan framework CodeIgniter. Adapun contoh perhitungan (Tirtana, 2019) menggunakan TF-IDF sebagai berikut:

Contoh daftar pekerjaan

1. job kebutuhan on-site support engineer pada project infrastructure lokasi penempatan jakarta spesifikasi s1 teknik informatika ilmu komputer teknik industri sma smk diploma tidak diproses syarat ipk minimal 3,00 diutamakan dapat berkomunikasi dengan baik bersedia bertugas travelling ke seluruh wilayah indonesia sehat jasmani dan rohani

2. requirements education degree dl sl gender female, age 30 years working time full time currently living in jakarta or surrounding area skill and experience in using fluent in japanese language intermediate to advance fluent in english basic to intermediate skill in using office word excel internet and email good interpersonal and communication skills good teamwork and hard worker

3. persyaratan dan kemampuan yang dibutuhkan pria wanita maksimal 28 tahun, belum menikah pendidikan s1 sistem informasi teknik informatika dengan ipk minimal 2,75 memiliki kemampuan dasar pemrograman yang kuat menguasai database oracle menguasai pembuatan tabel index prosedur function menguasai pemrograman dengan developer 2000 form report grafik memiliki loyalitas dan motivasi yang tinggi komunikatif kreatif dan inisatif mampu bekerja sama dalam tim berorientasi kepada target pengalaman tidak diutamakan

4. job on site support engineer for infrastructure project work location jakarta specification bachelor degree of computer science information engineering information system diploma or high school degree will be not processed male minimum 25 years old minimum gpa 3.00 at leats 3 years of experience in the same field having knowledge on computer networking, such as lan wan tcp ip pc mastering office applications able to speak english have good communication and able to work hard willing to be placed around Indonesia 
5. requirements memiliki pengalaman 1-2 tahun di bidang research development it atau it operations memiliki pengalaman dengan berbagai os windows unix linux dsb serta client server deployment memiliki pengalaman dengan berbagai jenis security devices dan banking peripheral mampu bekerja secara independen ataupun dalam kelompok

Dari daftar pekerjaan di atas dilakukan perhitungan menggunakan metode TF-IDF sesuai dengan persamaan 1 sampai 4 di atas. Detail perhitungan dengan menggunakan keyword "Teknik Informatika" terdapat pada tabel 1 di bawah ini.

Tabel 1 Perhitungan TF-IDF

\begin{tabular}{|c|c|c|c|c|c|c|c|c|c|c|c|c|c|}
\hline \multirow{2}{*}{$\begin{array}{l}\text { Unique } \\
\text { Words }\end{array}$} & \multirow{2}{*}{$\begin{array}{l}\text { Doc. } \\
\text { Freq }\end{array}$} & \multicolumn{5}{|c|}{ Term Freq } & \multirow{2}{*}{$\begin{array}{l}\text { Unique } \\
\text { Words }\end{array}$} & \multirow{2}{*}{$\begin{array}{l}\text { Doc. } \\
\text { Freq }\end{array}$} & \multicolumn{5}{|c|}{ Term Freq } \\
\hline & & \multirow{2}{*}{$\begin{array}{c}\text { ID. } 1 \\
74\end{array}$} & \multirow{2}{*}{$\begin{array}{c}\text { ID. } 2 \\
59\end{array}$} & \multirow{2}{*}{$\begin{array}{c}\text { ID. } 3 \\
66\end{array}$} & \multirow{2}{*}{$\begin{array}{c}\text { ID. } 4 \\
81\end{array}$} & \multirow{2}{*}{$\begin{array}{c}\text { ID. } 5 \\
43\end{array}$} & & & \multirow{2}{*}{$\begin{array}{c}\text { ID. } \\
1 \\
74\end{array}$} & \multirow{2}{*}{$\begin{array}{l}\text { ID. } \\
2 \\
59\end{array}$} & \multirow{2}{*}{$\begin{array}{c}\text { ID. } 3 \\
66\end{array}$} & \multirow{2}{*}{$\begin{array}{c}\text { ID. } 4 \\
81\end{array}$} & ID. 5 \\
\hline Word Co & & & & & & & Word Cou & & & & & & 43 \\
\hline job & 2 & 0.0135 & 0 & 0 & 0.0123 & 0 & dibutuhkan & 1 & 0 & 0 & 0.0152 & 0 & 0 \\
\hline kebutuhan & 1 & 0.0135 & 0 & 0 & 0 & 0 & pria & 1 & 0 & 0 & 0.0152 & 0 & 0 \\
\hline on-site & 1 & 0.0135 & 0 & 0 & 0 & 0 & tahun, & 1 & 0 & 0 & 0.0152 & 0 & 0 \\
\hline support & 2 & 0.0135 & 0 & 0 & 0.0123 & 0 & belum & 1 & 0 & 0 & 0.0152 & 0 & 0 \\
\hline engineer & 2 & 0.0135 & 0 & 0 & 0.0123 & 0 & menikah & 1 & 0 & 0 & 0.0152 & 0 & 0 \\
\hline pada & 1 & 0.0135 & 0 & 0 & 0 & 0 & pendidikan & 1 & 0 & 0 & 0.0152 & 0 & 0 \\
\hline project & 2 & 0.0135 & 0 & 0 & 0.0123 & 0 & sistem & 1 & 0 & 0 & 0.0152 & 0 & 0 \\
\hline infrastructure & 2 & 0.0135 & 0 & 0 & 0.0123 & 0 & informasi & 1 & 0 & 0 & 0.0152 & 0 & 0 \\
\hline lokasi & 1 & 0.0135 & 0 & 0 & 0 & 0 & 2,75 & 1 & 0 & 0 & 0.0152 & 0 & 0 \\
\hline penempatan & 1 & 0.0135 & 0 & 0 & 0 & 0 & dasar & 1 & 0 & 0 & 0.0152 & 0 & 0 \\
\hline jakarta & 3 & 0.0135 & 0.0169 & 0 & 0.0123 & 0 & pemrograman & 1 & 0 & 0 & 0.0005 & 0 & 0 \\
\hline spesifikasi & 1 & 0.0135 & 0 & 0 & 0 & 0 & kuat & 1 & 0 & 0 & 0.0152 & 0 & 0 \\
\hline s1 & 3 & 0.0135 & 0.0169 & 0.0152 & 0 & 0 & database & 1 & 0 & 0 & 0.0152 & 0 & 0 \\
\hline teknik & 2 & 0.0004 & 0 & 0.0152 & 0 & 0 & oracle & 1 & 0 & 0 & 0.0152 & 0 & 0 \\
\hline informatika & 2 & 0.0135 & 0 & 0.0152 & 0 & 0 & pembuatan & 1 & 0 & 0 & 0.0152 & 0 & 0 \\
\hline ilmu & 1 & 0.0135 & 0 & 0 & 0 & 0 & tabel & 1 & 0 & 0 & 0.0152 & 0 & 0 \\
\hline komputer & 1 & 0.0135 & 0 & 0 & 0 & 0 & index & 1 & 0 & 0 & 0.0152 & 0 & 0 \\
\hline industri & 1 & 0.0135 & 0 & 0 & 0 & 0 & prosedur & 1 & 0 & 0 & 0.0152 & 0 & 0 \\
\hline sma & 1 & 0.0135 & 0 & 0 & 0 & 0 & function & 1 & 0 & 0 & 0.0152 & 0 & 0 \\
\hline smk & 1 & 0.0135 & 0 & 0 & 0 & 0 & developer & 1 & 0 & 0 & 0.0152 & 0 & 0 \\
\hline diploma & 2 & 0.0135 & 0 & 0 & 0.0123 & 0 & 2000 & 1 & 0 & 0 & 0.0152 & 0 & 0 \\
\hline tidak & 2 & 0.0135 & 0 & 0.0152 & 0 & 0 & form & 1 & 0 & 0 & 0.0152 & 0 & 0 \\
\hline diproses & 1 & 0.0135 & 0 & 0 & 0 & 0 & report & 1 & 0 & 0 & 0.0152 & 0 & 0 \\
\hline syarat & 1 & 0.0135 & 0 & 0 & 0 & 0 & grafik & 1 & 0 & 0 & 0.0152 & 0 & 0 \\
\hline ipk & 2 & 0.0135 & 0 & 0.0152 & 0 & 0 & loyalitas & 1 & 0 & 0 & 0.0152 & 0 & 0 \\
\hline minimal & 2 & 0.0004 & 0 & 0.0152 & 0 & 0 & motivasi & 1 & 0 & 0 & 0.0152 & 0 & 0 \\
\hline 3,00 & 1 & 0.0135 & 0 & 0 & 0 & 0 & tinggi & 1 & 0 & 0 & 0.0152 & 0 & 0 \\
\hline diutamakan & 2 & 0.0135 & 0 & 0.0152 & 0 & 0 & komunikatif & 1 & 0 & 0 & 0.0152 & 0 & 0 \\
\hline memiliki & 3 & 0.0135 & 0 & 0.0005 & 0 & $4 \mathrm{E}-05$ & kreatif & 1 & 0 & 0 & 0.0152 & 0 & 0 \\
\hline pengalaman & 3 & 0.0135 & 0 & 0.0152 & 0 & $4 \mathrm{E}-05$ & inisiatif & 1 & 0 & 0 & 0.0152 & 0 & 0 \\
\hline 3 & 2 & 0.0135 & 0 & 0 & 0.0123 & 0 & sama & 1 & 0 & 0 & 0.0152 & 0 & 0 \\
\hline tahun & 2 & 0.0004 & 0 & 0 & 0 & 0.0233 & tim & 1 & 0 & 0 & 0.0152 & 0 & 0 \\
\hline wanita & 2 & 0.0135 & 0 & 0.0152 & 0 & 0 & berorientasi & 1 & 0 & 0 & 0.0152 & 0 & 0 \\
\hline
\end{tabular}




\begin{tabular}{|c|c|c|c|c|c|c|c|c|c|c|c|c|c|}
\hline usia & 1 & 0.0135 & 0 & 0 & 0 & 0 & kepada & 1 & 0 & 0 & 0.0152 & 0 & 0 \\
\hline maksimal & 2 & 0.0135 & 0 & 0.0152 & 0 & 0 & target & 1 & 0 & 0 & 0.0152 & 0 & 0 \\
\hline 28 & 2 & 0.0135 & 0 & 0.0152 & 0 & 0 & on & 1 & 0 & 0 & 0 & 0.0003 & 0 \\
\hline menguasai & 2 & 0.0135 & 0 & $1 \mathrm{E}-05$ & 0 & 0 & site & 1 & 0 & 0 & 0 & 0.0123 & 0 \\
\hline aplikasi & 1 & 0.0135 & 0 & 0 & 0 & 0 & for & 1 & 0 & 0 & 0 & 0.0123 & 0 \\
\hline office & 3 & 0.0135 & 0.0169 & 0 & 0.0123 & 0 & work & 1 & 0 & 0 & 0 & 0.0003 & 0 \\
\hline mampu & 3 & 0.0004 & 0 & 0.0152 & 0 & 0.0233 & location & 1 & 0 & 0 & 0 & 0.0123 & 0 \\
\hline bekerja & 3 & 7E-06 & 0 & 0.0152 & 0 & 0.0233 & specification & 1 & 0 & 0 & 0 & 0.0123 & 0 \\
\hline dalam & 3 & 0.0135 & 0 & 0.0152 & 0 & 0.0233 & bachelor & 1 & 0 & 0 & 0 & 0.0123 & 0 \\
\hline bidang & 2 & 0.0135 & 0 & 0 & 0 & 0.0233 & of & 1 & 0 & 0 & 0 & 0.0003 & 0 \\
\hline dokumentasi & 1 & 0.0135 & 0 & 0 & 0 & 0 & computer & 1 & 0 & 0 & 0 & 0.0003 & 0 \\
\hline berbahasa & 1 & 0.0135 & 0 & 0 & 0 & 0 & science & 1 & 0 & 0 & 0 & 0.0123 & 0 \\
\hline inggris & 1 & 0.0135 & 0 & 0 & 0 & 0 & information & 1 & 0 & 0 & 0 & 0.0003 & 0 \\
\hline teliti & 1 & 0.0135 & 0 & 0 & 0 & 0 & engineering & 1 & 0 & 0 & 0 & 0.0123 & 0 \\
\hline dan & 3 & 7E-06 & 0 & $1 \mathrm{E}-05$ & 0 & 0.0233 & system & 1 & 0 & 0 & 0 & 0.0123 & 0 \\
\hline dengan & 3 & 0.0004 & 0 & 0.0005 & 0 & 0.0011 & high & 1 & 0 & 0 & 0 & 0.0123 & 0 \\
\hline deadline & 1 & 0.0135 & 0 & 0 & 0 & 0 & school & 1 & 0 & 0 & 0 & 0.0123 & 0 \\
\hline sanggup & 1 & 0.0135 & 0 & 0 & 0 & 0 & will & 1 & 0 & 0 & 0 & 0.0123 & 0 \\
\hline keras & 1 & 0.0135 & 0 & 0 & 0 & 0 & be & 1 & 0 & 0 & 0 & 0.0003 & 0 \\
\hline dapat & 1 & 0.0135 & 0 & 0 & 0 & 0 & not & 1 & 0 & 0 & 0 & 0.0123 & 0 \\
\hline berkomunikasi & 1 & 0.0135 & 0 & 0 & 0 & 0 & processed & 1 & 0 & 0 & 0 & 0.0123 & 0 \\
\hline baik & 1 & 0.0135 & 0 & 0 & 0 & 0 & male & 1 & 0 & 0 & 0 & 0.0123 & 0 \\
\hline bersedia & 1 & 0.0135 & 0 & 0 & 0 & 0 & minimun & 1 & 0 & 0 & 0 & 0.0123 & 0 \\
\hline bertugas & 1 & 0.0135 & 0 & 0 & 0 & 0 & 25 & 1 & 0 & 0 & 0 & 0.0123 & 0 \\
\hline travelling & 1 & 0.0135 & 0 & 0 & 0 & 0 & old & 1 & 0 & 0 & 0 & 0.0123 & 0 \\
\hline ke & 1 & 0.0135 & 0 & 0 & 0 & 0 & minimum & 1 & 0 & 0 & 0 & 0.0123 & 0 \\
\hline seluruh & 1 & 0.0135 & 0 & 0 & 0 & 0 & gpa & 1 & 0 & 0 & 0 & 0.0123 & 0 \\
\hline wilayah & 1 & 0.0135 & 0 & 0 & 0 & 0 & 3 & 1 & 0 & 0 & 0 & 0.0123 & 0 \\
\hline indonesia & 2 & 0.0135 & 0 & 0 & 0.0123 & 0 & at & 1 & 0 & 0 & 0 & 0.0123 & 0 \\
\hline sehat & 1 & 0.0135 & 0 & 0 & 0 & 0 & least & 1 & 0 & 0 & 0 & 0.0123 & 0 \\
\hline jasmani & 1 & 0.0135 & 0 & 0 & 0 & 0 & the & 1 & 0 & 0 & 0 & 0.0123 & 0 \\
\hline rohani & 1 & 0.0135 & 0 & 0 & 0 & 0 & same & 1 & 0 & 0 & 0 & 0.0123 & 0 \\
\hline requirements & 2 & 0 & 0.0169 & 0 & 0 & 0.0233 & field & 1 & 0 & 0 & 0 & 0.0123 & 0 \\
\hline education & 1 & 0 & 0.0169 & 0 & 0 & 0 & having & 1 & 0 & 0 & 0 & 0.0123 & 0 \\
\hline degree & 2 & 0 & 0.0169 & 0 & 0.0003 & 0 & knowledge & 1 & 0 & 0 & 0 & 0.0123 & 0 \\
\hline $\mathrm{d} 1$ & 1 & 0 & 0.0169 & 0 & 0 & 0 & networking, & 1 & 0 & 0 & 0 & 0.0123 & 0 \\
\hline gender & 1 & 0 & 0.0169 & 0 & 0 & 0 & such & 1 & 0 & 0 & 0 & 0.0123 & 0 \\
\hline female. & 1 & 0 & 0.0169 & 0 & 0 & 0 & as & 1 & 0 & 0 & 0 & 0.0123 & 0 \\
\hline age & 1 & 0 & 0.0169 & 0 & 0 & 0 & lan & 1 & 0 & 0 & 0 & 0.0123 & 0 \\
\hline 30 & 1 & 0 & 0.0169 & 0 & 0 & 0 & wan & 1 & 0 & 0 & 0 & 0.0123 & 0 \\
\hline years & 2 & 0 & 0.0169 & 0 & 0.0003 & 0 & tcp & 1 & 0 & 0 & 0 & 0.0123 & 0 \\
\hline working & 1 & 0 & 0.0169 & 0 & 0 & 0 & ip & 1 & 0 & 0 & 0 & 0.0123 & 0 \\
\hline time & 1 & 0 & 0.0006 & 0 & 0 & 0 & $\mathrm{pc}$ & 1 & 0 & 0 & 0 & 0.0123 & 0 \\
\hline full & 1 & 0 & 0.0169 & 0 & 0 & 0 & mastering & 1 & 0 & 0 & 0 & 0.0123 & 0 \\
\hline
\end{tabular}




\begin{tabular}{|c|c|c|c|c|c|c|c|c|c|c|c|c|c|}
\hline currently & 1 & 0 & 0.0169 & 0 & 0 & 0 & applications & 1 & 0 & 0 & 0 & 0.0123 & 0 \\
\hline living & 1 & 0 & 0.0169 & 0 & 0 & 0 & able & 1 & 0 & 0 & 0 & 0.0003 & 0 \\
\hline in & 2 & 0 & 0 & 0 & 0.0123 & 0 & speak & 1 & 0 & 0 & 0 & 0.0123 & 0 \\
\hline or & 2 & 0 & 0.0169 & 0 & 0.0123 & 0 & have & 1 & 0 & 0 & 0 & 0.0123 & 0 \\
\hline surrounding & 1 & 0 & 0.0169 & 0 & 0 & 0 & willing & 1 & 0 & 0 & 0 & 0.0123 & 0 \\
\hline area & 1 & 0 & 0.0169 & 0 & 0 & 0 & placed & 1 & 0 & 0 & 0 & 0.0123 & 0 \\
\hline skill & 1 & 0 & 0.0006 & 0 & 0 & 0 & around & 1 & 0 & 0 & 0 & 0.0123 & 0 \\
\hline and & 2 & 0 & $3 \mathrm{E}-07$ & 0 & 0.0123 & 0 & 2-Jan & 1 & 0 & 0 & 0 & 0 & 0.0233 \\
\hline experience & 2 & 0 & 0.0169 & 0 & 0.0123 & 0 & di & 1 & 0 & 0 & 0 & 0 & 0.0233 \\
\hline using & 1 & 0 & 0.0006 & 0 & 0 & 0 & research & 1 & 0 & 0 & 0 & 0 & 0.0233 \\
\hline fluent & 1 & 0 & 0.0006 & 0 & 0 & 0 & development & 1 & 0 & 0 & 0 & 0 & 0.0233 \\
\hline japanese & 1 & 0 & 0.0169 & 0 & 0 & 0 & it & 1 & 0 & 0 & 0 & 0 & 0.0011 \\
\hline language & 1 & 0 & 0.0006 & 0 & 0 & 0 & atau & 1 & 0 & 0 & 0 & 0 & 0.0233 \\
\hline intermediate & 1 & 0 & 0.0006 & 0 & 0 & 0 & operations & 1 & 0 & 0 & 0 & 0 & 0.0233 \\
\hline to & 2 & 0 & 0.0006 & 0 & $6 \mathrm{E}-06$ & 0 & berbagai & 1 & 0 & 0 & 0 & 0 & 0.0011 \\
\hline advance & 1 & 0 & 0.0169 & 0 & 0 & 0 & os & 1 & 0 & 0 & 0 & 0 & 0.0233 \\
\hline english & 2 & 0 & 0.0169 & 0 & 0.0123 & 0 & windows & 1 & 0 & 0 & 0 & 0 & 0.0233 \\
\hline basic & 1 & 0 & 0.0169 & 0 & 0 & 0 & unix & 1 & 0 & 0 & 0 & 0 & 0.0233 \\
\hline word & 1 & 0 & 0.0169 & 0 & 0 & 0 & linux & 1 & 0 & 0 & 0 & 0 & 0.0233 \\
\hline excel & 1 & 0 & 0.0169 & 0 & 0 & 0 & dsb & 1 & 0 & 0 & 0 & 0 & 0.0233 \\
\hline internet & 1 & 0 & 0.0169 & 0 & 0 & 0 & serta & 1 & 0 & 0 & 0 & 0 & 0.0233 \\
\hline email & 1 & 0 & 0.0169 & 0 & 0 & 0 & client & 1 & 0 & 0 & 0 & 0 & 0.0233 \\
\hline good & 2 & 0 & 0.0006 & 0 & 0.0123 & 0 & server & 1 & 0 & 0 & 0 & 0 & 0.0233 \\
\hline interpersonal & 1 & 0 & 0.0169 & 0 & 0 & 0 & deployment & 1 & 0 & 0 & 0 & 0 & 0.0233 \\
\hline communication & 2 & 0 & 0.0169 & 0 & 0.0123 & 0 & jenis & 1 & 0 & 0 & 0 & 0 & 0.0233 \\
\hline skills & 1 & 0 & 0.0169 & 0 & 0 & 0 & security & 1 & 0 & 0 & 0 & 0 & 0.0233 \\
\hline teamwork & 1 & 0 & 0.0169 & 0 & 0 & 0 & devices & 1 & 0 & 0 & 0 & 0 & 0.0233 \\
\hline hard & 2 & 0 & 0.0169 & 0 & 0.0123 & 0 & banking & 1 & 0 & 0 & 0 & 0 & 0.0233 \\
\hline worker & 1 & 0 & 0.0169 & 0 & 0 & 0 & peripheral & 1 & 0 & 0 & 0 & 0 & 0.0233 \\
\hline persyaratan & 1 & 0 & 0 & 0.0152 & 0 & 0 & secara & 1 & 0 & 0 & 0 & 0 & 0.0233 \\
\hline kemampuan & 1 & 0 & 0 & 0.0005 & 0 & 0 & independen & 1 & 0 & 0 & 0 & 0 & 0.0233 \\
\hline yang & 1 & 0 & 0 & $1 \mathrm{E}-05$ & 0 & 0 & ataupun & 1 & 0 & 0 & 0 & 0 & 0.0233 \\
\hline & & & & & & & kelompok & 1 & 0 & 0 & 0 & 0 & 0.0233 \\
\hline
\end{tabular}

Dari hasil perhitungan pada tabel 1 perhitungan TF IDF di atas didapatkan hasil perhitungan TF-IDF pada tabel 2 berikut ini.

Tabel 2 Hasil Perhitungan TF-IDF

\begin{tabular}{|c|c|}
\hline Dokumen & Nilai TF-IDF \\
\hline 1 & 0,038 \\
\hline 2 & 0 \\
\hline 3 & 0,082 \\
\hline 4 & 0 \\
\hline 5 & 0 \\
\hline
\end{tabular}

Dari hasil perhitugan TF-IDF pada tabel 2 di atas, didapatkan bahwa dokumen 3 memiliki korelasi dengan query yang dimasukkan oleh user paling sesuai dengan nilai 0,082 dan selanjutnya dokumen 1 dengan nilai 0,038. Maka hasil yang ditampilkan pada halaman hasil pencarian sesuai dengan perangkingan metode TF-IDF. 
Setelah melakukan perhitungan di atas, tahap selanjutnya adalah membuat algoritma pemrograman untuk mengimplementasikan metode diatas. Tahap keempat adalah pembuatan programsesuai dengan arsitektur sistem temu kembali informasi yang terdapat pada gambar 1, dan tahap terakhir adalah pengujian sistem, menggunakan metode blackboxdengan metode BVA. Setelah dilakukan pengujian maka hasil pengujian tersebut dilakukan analisis dan pembahasan sehingga dapat ditarik kesimpulan dari penelitian yang telah dilakukan. Adapun detail dari metodologi penelitian terdapat pada gambar 2 di bawah ini.

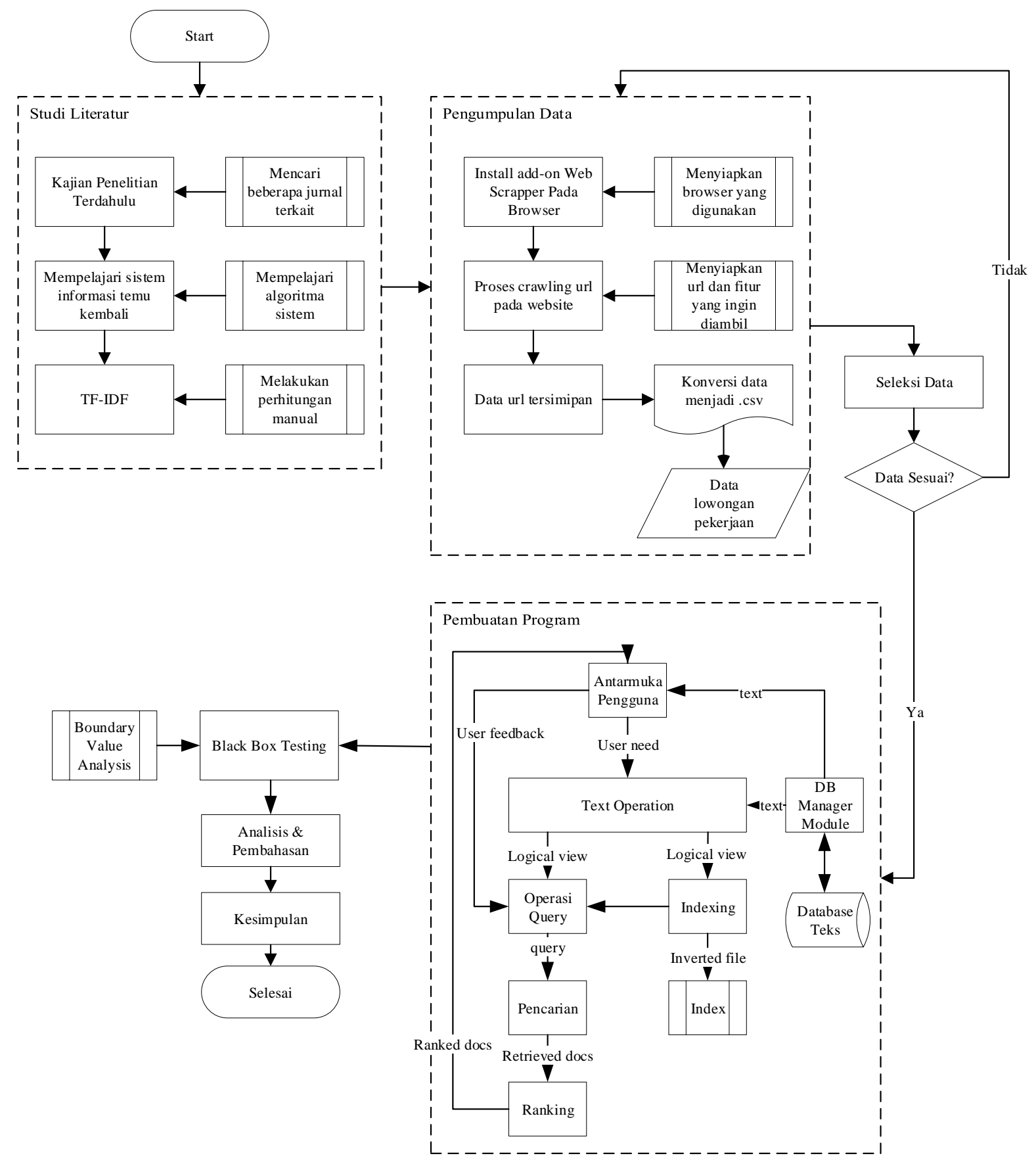

Gambar 2 Metodologi Penelian

Secara spesifik tahap pengembangan dari model RAD seperti yang telah dijelaskan pada landasan teori terdiri dari tiga tahap yaitu, tahap perencanaan kebutuhan (requirement planning), tahap desain (desain), dan tahap implementasi (implementation). 
Pada tahap pertama yaitu menentukan rencana kebutuhan (requirement planning), antara lain kebutuhan perangkat keras, perangkat lunak, kebutuhan input, kebutuhan informasi, dan kebutuhan antar muka. Adapun secara detail kebutuhan terdapat pada keterangan di bawah ini:

1. Kebutuhan Perangkat Keras
a. Prosesor
: AMD Ryzen 5 2500U APU (2GHZ 3,6GHZ)
b. Memori
: 1228 MB DDR4 2400 MHZ
c. Kartu Grafis
: AMD Radeon Vega 8 Graphics
d. Harddisk
: HDD 1 TB dan SSD 128 GB
e. Sistem Operasi
: Windows 10

2. Kebutuhan Perangkat Lunak
a. XAMPP Control Panel
b. Navicat Premium 12
c. Visual Studio Code
d. Browser Google Chrome
e. Bahasa Pemrograman PHP dengan framework CodeIgniter

3. Kebutuhan Antarmuka Pengguna (user interface)

Kebutuhan antarmuka pengguna antara lain, tampilan administrator, tampilan pengguna, dan tampilan hasil pencarian pengguna.Secara spesifik use case diagram dari sistem yang dibuat terdapat pada gambar 3 di bawah ini.

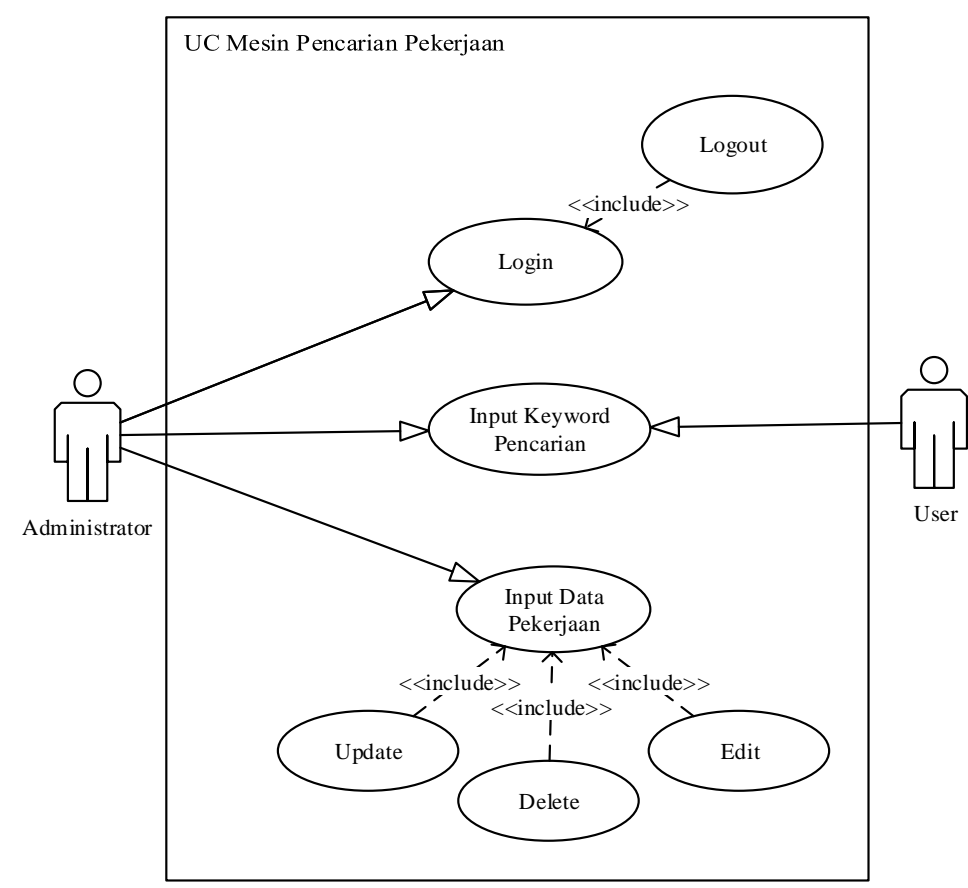

Gambar 3 Use Case Diagram

\section{HASIL DAN PEMBAHASAN}

\section{a) Implementasi Antarmuka Pengguna}

Pada halaman implementasi antarmuka pengguna (user interface) ini terdiri dari halaman login administrator, halaman input keyword (query), dan halaman menampilkan hasil pencarian user.Secara berturut akan ditampilkan pada halaman di bawah ini.

\section{Halaman Login Admin}

Pada halaman login administrator terdapat dua textbox, yang pertama user dapat memasukkan email yang digunakan sebagai username dan password.Secara lebih detail halaman login administrator terdapat pada gambar 4. 


\section{JobFinder Login}

Start an admin session

Enter email
Password

\section{Gambar 4 Login Administrator}

\section{Halaman Input Keyword}

Pada halaman input keyword terdapat satu buahtextboxyang berfungsi untuk memasukkan input berupa query yang akan diolah oleh sistem pencarian dan kemudian. Secara lebih detail halaman input keyword terdapat pada gambar 5 di bawah ini.
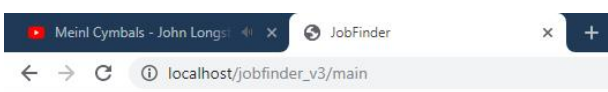

\section{JobFinder}

Don't miss up any opportunity in your face!

\section{Gambar 5 Input Keyword}

\section{Halaman Lihat Hasil Pencarian}

Pada halaman lihat hasil pencarian, user dapat melihat hasil pencarian sesuai dengan query yang dimasukkan, dan user dapat memasukkan query lain apabila ingin mencari lowongan pekerjaan dengan keyword yang lain. 


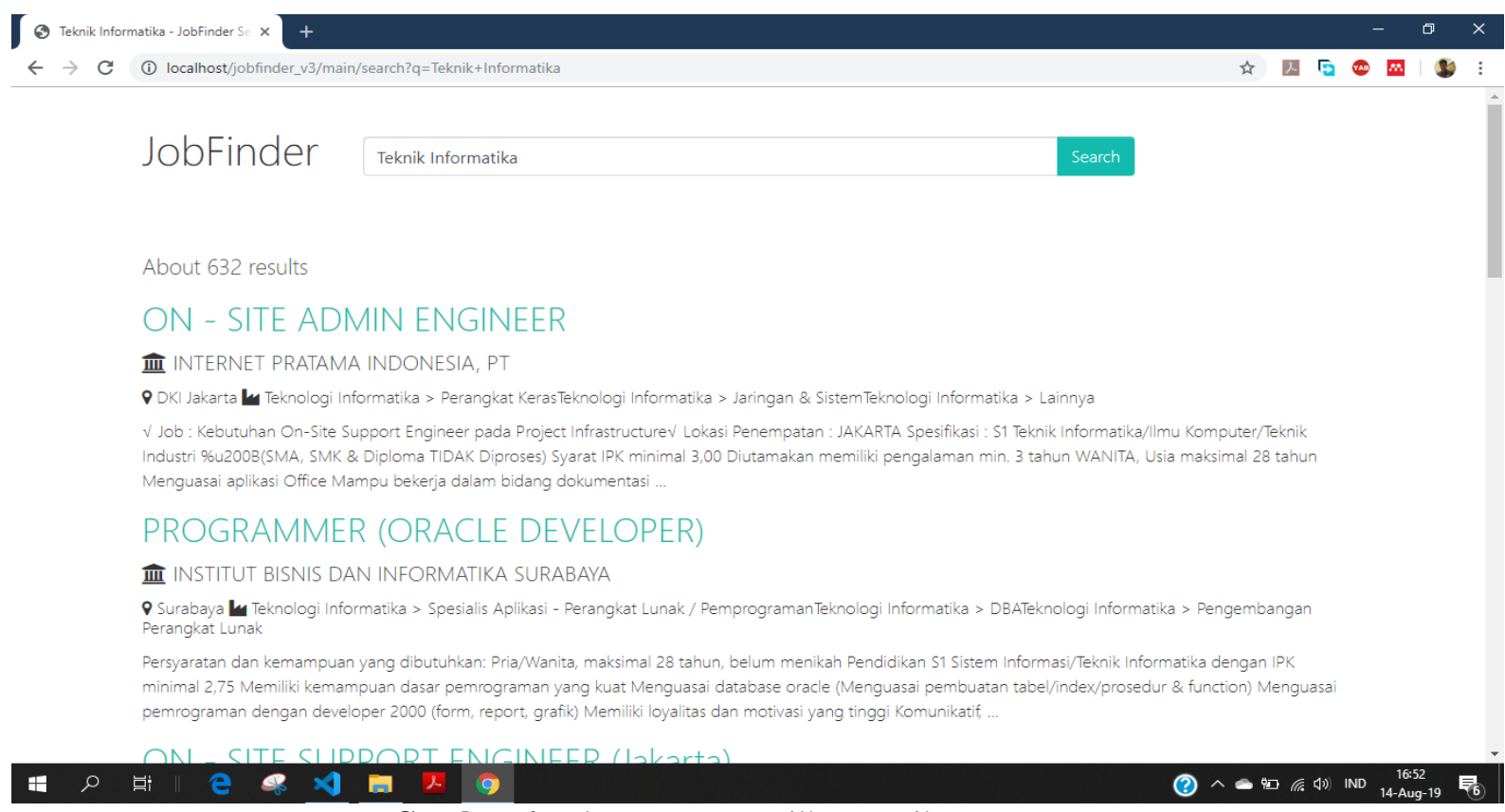

Gambar 6 Halaman Menampilkan Hasil Query

\section{b) Pengujian Sistem}

1. Tahap pengujian sistem yang pertama yaitu menggunakan metode black box dengan menggunakan Boundary Value Analysis (BVA). Pertama adalah menentukan skenario yang akan diujikan terutama yaitu untuk kolom textfieldyang ada pada sistem.Pada tabel 3 akan dijelaskan mengenai skenario pengujian pada kolom username dan password untuk login administrator, dan pada tabel 4 akan dilakukan pengujian untuk textfield dari mesin pencari yang telah dibuat.

Tabel 3 Hasil Uji Field Username dan Password

\begin{tabular}{|c|c|c|c|c|}
\hline $\begin{array}{c}\text { Data Sampel } \\
\text { Username }\end{array}$ & $\begin{array}{c}\text { Data Sampel } \\
\text { Password }\end{array}$ & Perkiraan Hasil & Hasil & Kesimpulan \\
\hline admin & admin & TRUE & TRUE & Success \\
\hline Admin & password & FALSE & FALSE & Success \\
\hline administrator & administrator & FALSE & FALSE & Success \\
\hline admin 1 & admin & FALSE & FALSE & Success \\
\hline
\end{tabular}

Tabel 4 Hasil Uji Field Input Query

\begin{tabular}{|c|c|c|c|}
\hline $\begin{array}{c}\text { Data Sampel } \\
\text { Username }\end{array}$ & Perkiraan Hasil & Hasil & Kesimpulan \\
\hline Teknik Informatika & TRUE & TRUE & Success \\
\hline Programmer & TRUE & TRUE & Success \\
\hline Database & TRUE & TRUE & Success \\
\hline Web & TRUE & TRUE & Success \\
\hline
\end{tabular}

2. Tahap pengujian sistem yang kedua yaitu membandingkan waktu komputasi antara sistem menggunakan metode TF-IDF dan tanpa menggunakan (full query). Tabel perbandingan waktu komputasi dapat dilihat pada tabel 5 di bawah ini.

Tabel 5 Perbandingan Waktu Komputasi

\begin{tabular}{lcccc}
\hline \hline \multicolumn{1}{c}{ Search Keyword } & \multicolumn{2}{c}{ Full Query } & \multicolumn{2}{c}{ TF-IDF } \\
& Hasil Pencarian & Waktu (s) & Hasil Pencarian & Waktu (s) \\
\hline Android Developer & 1.056 & 0,2567 & 456 & 0,9939 \\
IT Consultant & 4.680 & 0,1432 & 1.325 & 0,9071 \\
Web Designer & 2.667 & 0,1282 & 697 & 0,9581 \\
Web CodeIgniter & 2.652 & 0,14 & 699 & 0,991 \\
Sistem Analis & 908 & 0,1294 & 324 & 0,9304 \\
Android Web Developer & 2.961 & 0,1557 & 1.013 & 0,8943 \\
Rata-rata & & 0,1589 & & 0,9458 \\
\hline \hline
\end{tabular}




\section{KESIMPULAN DAN SARAN}

Kesimpulan pertama yang dapat ditarik dari penelitian yang telah dilakukan membuktikan bahwa sistem yang telah dibuat terbukti dapat menampilkan hasil query yang sesuai dengan keyword yang dimasukkan oleh pengguna. Kesimpulan kedua yang dapat ditarik adalah dengan penerapan metode TF-IDF terbukti bahwa hasil query yang ditampilkan menjadi lebih relevan jika dibandingkan dengan tanpa metode pembobotan (full query). Namun metode TF-IDF cenderung memakan waktu yang lebih lama jika dibandingkan dengan tanpa metode pembobotan (full query). Dengan rata-rata pencarian per kata kunci (keyword)jika tanpa menggunakan metode pembobotanyang dimasukkan oleh pengguna sebesar 0,1589 detik, sedangkan jika menggunakan metode pembobotan TF-IDF sebesar 0,9458.

Saran untuk pengembangan penelitian selanjutnya adalah dengan menambahkan metode praproses teks seperti tokenization, stemming, stopword removal dan filteringdari database lowongan pekerjaan, yang bertujuan untuk meningkatkan kecepatan komputasi dan meningkatkan tingkat akurasi keyword pencarian. Saran lain yaitu untuk menggunakan metode untuk mengukur kemiripan teks misalkan dengan menggunakan metode cosine similarity.

\section{DAFTAR RUJUKAN}

Anissatush Sholiha, Rochdi Wasono, T. W. U. (2010). FAKTOR-FAKTOR DOMINAN YANG MEMPENGARUHI LAMA MENCARI PEKERJAAN DI SEMARANG MENGGUNAKAN. 1-8.

Fitri, M. (2017). Perancangan Sistem Temu Balik Informasi Dengan Metode Pembobotan Kombinasi TF-IDF Untuk Pencarian Dokumen Berbahasa Indonesia. 41(1), 19-25.

Putu Wuri Handayani, I Made Wiryana, J.-T. M. (2017). Mesin Pencari Berbasiskan Semantik Untuk Bahasa Indonesia. Jurnal Sistem Informasi MTI-UI, 4(January), 1-12.

Ria Melita, Victor Amrizal, Hendra Bayu Suseno, T. D. (2018). Penerapan Metode Term Frequency Inverse Document Frequency (Tf-Idf) Dan Cosine Similarity Pada Sistem Temu Kembali Informasi Untuk Mengetahui Syarah Hadits Berbasis Web (Studi Kasus: Hadits Shahih Bukhari-Muslim). Jurnal Teknik Informatika, 11(2), 149-164. https://doi.org/10.15408/jti.v11i2.8623

Statistik, B. P. (2019). Berita Resmi Statistik Keadaan Ketenagakerjaan Indonesia Februari 2019. 5(41), 1-16.

Tirtana, A. (2019). Sistem Pendukung Keputusan Kelompok Untuk Menentukan Penerima AGC Award Menggunakan Metode Simple Additive Weighting dan Borda. Jurnal Informatika: Jurnal Pengembangan IT, 4(1), 43-47. https://doi.org/10.30591/jpit.v4i1.1062 